\title{
Mothers' Health Care of their Children with Leukemia
}

\author{
Amira A. Elfattah ${ }^{1}$, Hanaa A. Abd El-megeed ${ }^{2}$, Samah Said Sabry ${ }^{3}$ \\ ${ }^{1}$ B.Sc. Nursing Science, ${ }^{2}$ Prof of Community Health Nursing, Faculty of Nursing, Benha \\ University, ${ }^{3}$ Lecturer of Community Health Nursing, Faculty of Nursing, Benha \\ University
}

\begin{abstract}
Children having leukemic usually suffer from many health problem as a result of the disease process. The purpose of the study was to assess knowledge and practices provided by mothers for the care of their children having leukemia. Research design: A descriptive research design was utilized to conduct this study. Setting: The present study was conducted at out- patient clinic of pediatric oncology in the National Cancer Institute at Cairo University. Sample: A simple random sample was used to collect the total number of the sample was 366 mothers. One instrument was used; A) structured interviewing questionnaire it had four parts: 1. Demographic characteristic of the children, 2. Demographic characteristics of the mothers, 3. Exposure of the mothers to risk factors of leukemia, 4. Medical history of the disease as past and present history. B). Mothers' knowledge questionnaire sheet, C). Reported practices questionnaire sheet. Results: $64.2 \%$ of studied sample had poor knowledge, $83.3 \%$ had satisfactory total reported practices. Conclusion: An approximately two thirds of mothers $(64.2 \%)$ had poor knowledge. Where more than three quarters of them had satisfactory practices (83.3\%).Recommendation: Health education programs for mothers who having children with leukemia to prepare them with needed knowledge and skills. This study can be applied on a larger sample at other setting.
\end{abstract}

Key words: Leukemia, Knowledge, Practices.

\section{Introduction}

Childhood is a period of play, physical, mental, social, emotional growth, and development, creation, hyperactivity, stress, strain, responsible to school and educational environment. School age constitutes a big sector of the population. The children are a god's gift for a family, child has been more vital, gentle, joyous, trustful, curious, courageous and more innovative than adult, children bring happiness and makes a family a whole, children health have to be family health (James et al., 2015).

Leukemia is a cancer of bone marrow characterized by over production of abnormal white blood cells that range from very primitive and immature to nearly normal. The abnormal cells cannot defend the body against microorganisms and tissue injuries. Leukemia has three major effects; increased number of abnormal, immature leukocytes; accumulations of these cells within the lymph nodes, spleen, and other organs. Treatment of leukemia is increasing the overall the last 5-year survival rates for childhood cancers are approximately $80 \%$, cancer is still the second leading cause of death(following accidents) in children aged from 8-18 years old (Leukemia and Lymphoma Society, 2017).

A community health nurse plays a critical role to educate family members, friends, school personnel and healthcare providers about possible long-term and late effects of treatment, guide the parent to help the leukemic child to live within normal life between the family and their peers, and communicate with teachers about the child's need. The well-being of the community served is the community health nurse's primary goal and is achieved through the education of community members on health practices and disease prevention, the 
basic element of community health nursing are promotion of healthful living, prevention of health problems, treatment of disorders and rehabilitation (Follin et al., 2014).

\section{Significance of the study}

Leukemia is a cancer of bone marrow, the soft inner part of bones where new blood cells are made, leukemia account for approximately $14 \%$ of all deaths worldwide, estimated 12.66 million new cancer cases and 7.56 million deaths occurred in 2011 worldwide, and it is the second leading death in developed world. By 2030, there will be almost 21.4 million new cases annually diagnosed (James et al., 2015).

Leukemia developed in 352,000 people globally and caused 265,000 deaths. It is the most common type of cancer in children. With three quarters of leukemia cases in children being the acute lymphoblastic type. It occurs more commonly in the developed world (American cancer society, 2017).

In Egypt, childhood leukemia is the most common childhood malignancy, it represents $33.2 \%$ of all childhood malignancies, and those children represent $73.3 \%$ of all leukemic children in National Cancer Institute, Cairo University. More than 65 million mothers play a major role in maximizing the health and quality of life of individuals with acute and chronic leukemia (National cancer institute, 2018). A recent forecast modeling study for mothers' health care of their children with leukemia.

\section{Purpose}

The purpose of this study was to assess the knowledge and practices are provided by mothers for the care of their children having leukemia.

1. Assessing the mothers' knowledge regarding to leukemia.
2. Assessing the mothers' practices regarding to care of their leukemic children.

\section{Research Questions:}

1. What is the level of mothers' knowledge score regarding leukemia?

2. What is the level of mothers' practices for the care of their children having leukemia?

\section{Subjects and Methods}

\section{Research Design: -}

A descriptive research design was utilized to conduct this study.

\section{Setting:-}

The present study was conducted at out-patient clinic of pediatric oncology at National Cancer Institute Cairo University.

\section{Sampling:-}

Simple random sample was used in this study. The total number of children diagnosed with leukemia was 4320.The size was determined according to the following equation

$$
\mathrm{n}=\frac{\mathrm{N}}{1+\mathrm{N}(\mathrm{e}) 2}
$$

Criteria of the sample: Children should range from 5-14 years.

\section{Instruments:}

Instrument one:-A structured interview questionnaire it is developed by the researcher to collect data about characteristics of the sample it included three parts:

1) Part A: It included four parts:

- Demographic characteristic of the children, 
- The socio characteristic of the mothers' as, Age, education, occupation, etc......

- Exposure of the mothers to risk factors of leukemia,

- Medical history of the disease as past and present history.
2) Part B. Mothers' knowledge about meaning of leukemia, diagnosis of leukemia, treatments, etc.....

3) Part C. Mothers reported practices for the care of their children with leukemia such as care of symptoms and side effects of chemotherapy as bleeding, nausea and vomiting, hyperthermia, infection, etc......

\section{Results}

Table (1): Distributions of studied children regarding their demographic characteristics $(n=366)$.

\begin{tabular}{|c|c|c|}
\hline Demographic Characteristics of the children & No & $\%$ \\
\hline \multicolumn{3}{|l|}{ Age /year } \\
\hline $5-$ & 142 & 38.8 \\
\hline $8-$ & 114 & 31.1 \\
\hline $11+$ & 110 & 30.1 \\
\hline Mean \&SD & \multicolumn{2}{|c|}{$9.3 \pm 2.6$} \\
\hline \multicolumn{3}{|l|}{ Gender } \\
\hline Male & 237 & 64.8 \\
\hline Female & 129 & 35.2 \\
\hline \multicolumn{3}{|l|}{ Residence } \\
\hline Rural & 263 & 71.9 \\
\hline Urban & 103 & 28.1 \\
\hline \multicolumn{3}{|l|}{ Education } \\
\hline Can't Read \& Write & 90 & 24.6 \\
\hline Read \& Write & 70 & 19.1 \\
\hline Primary & 147 & 40.2 \\
\hline Preparatory & 59 & 16.1 \\
\hline \multicolumn{3}{|l|}{ Birth order } \\
\hline First & 95 & 25.0 \\
\hline Second & 138 & 44.4 \\
\hline Third or more & 133 & 30.6 \\
\hline $\begin{array}{l}\text { able (1): Showed that, } 38.8 \% \text { of the } \\
\text { ildren aged from } 5-8 \text { years old with } \\
\text { e mean age }(9.3 \pm 2.6) \text { years, and } \\
.8 \% \text { were males, while } 71.9 \% \text { were }\end{array}$ & $\begin{array}{l}\text { living } \\
\text { primar } \\
\text { leuken } \\
\text { child it }\end{array}$ & $\begin{array}{l}\text {, } 40.2 \% \text { had } \\
\text { and } 44.4 \% \\
\text { ere the second }\end{array}$ \\
\hline
\end{tabular}


Table (2): Distribution of studied mothers regarding their demographic characteristics

$$
(n=366) \text {. }
$$

\begin{tabular}{|l|c|c||}
\hline Demographic Characteristics of mothers & NO & $\%$ \\
\hline \hline Age/ Year & 60 & 16.4 \\
\hline $18-$ & 161 & 44.0 \\
\hline $25-$ & 145 & 39.6 \\
\hline $32+$ & $\mathbf{2 9 . 8 \pm 6 . 1}$ \\
\hline Mean \&SD & 232 & 63.4 \\
\hline Marital status & 56 & 15.3 \\
\hline Married & 78 & 21.3 \\
\hline Widow & \multicolumn{3}{|l|}{} \\
\hline Divorced & 183 & 50.0 \\
\hline Occupation & 183 & 50.0 \\
\hline Worker & \multicolumn{3}{|l|}{} \\
\hline Not working &
\end{tabular}

Table (2): Demonstrated that, $44.0 \%$ of the mothers aged from 25-32 years with mean age $29.8 \pm 6.1,63.4 \%$ of mothers were married and equal percent $50.0 \%$ between worker and not working mothers.

Table (3): Distribution of studied mothers regarding to their exposure of risk factors of leukemia $(n=366)$.

\begin{tabular}{|c|c|c|}
\hline Exposure the mothers to the risk factors of leukemia & NO & $\%$ \\
\hline \multicolumn{3}{|l|}{ Exposure to radiation in the first trimester of pregnancy } \\
\hline Yes & 166 & 45.4 \\
\hline No & 200 & 54.6 \\
\hline \multicolumn{3}{|l|}{ Parents' consanguinity } \\
\hline Yes & 159 & 43.4 \\
\hline No & 207 & 56.6 \\
\hline \multicolumn{3}{|l|}{ Mothers smoking } \\
\hline Yes & 0 & 0.0 \\
\hline No & 366 & 100.0 \\
\hline \multicolumn{3}{|l|}{ Exposed to smoke at home } \\
\hline Yes & 259 & 70.8 \\
\hline No & 107 & 29.2 \\
\hline
\end{tabular}

Table (3): Demonstrated that, $54.6 \%$ of the mothers were not exposed to radiation in the first trimester of pregnancy, $56.6 \%$ had no consanguinity, while all mothers didn't smoke and $70.8 \%$ had exposed to smoke at home. 
Table (4): Distribution of studied mothers regarding their knowledge about leukemia $(n=366)$.

\begin{tabular}{|c|c|c|c|c|c|c|}
\hline \multirow{2}{*}{$\begin{array}{l}\text { Mothers knowledge about } \\
\text { Leukemia }\end{array}$} & \multicolumn{2}{|c|}{ Correct Complete } & \multicolumn{2}{|c|}{ Correct Incomplete } & \multicolumn{2}{|c|}{ Incorrect } \\
\hline & No. & $\%$ & No. & $\%$ & No. & $\%$ \\
\hline \multicolumn{7}{|l|}{ Leukemia } \\
\hline Meaning & 154 & 42.1 & 72 & 19.7 & 140 & 38.2 \\
\hline Predisposing factors & 16 & 4.4 & 217 & 59.3 & 133 & 36.3 \\
\hline Types & 21 & 5.7 & 130 & 35.5 & 215 & 58.8 \\
\hline Commonly affected age group & 245 & 66.9 & 0 & 0.0 & 121 & 33.1 \\
\hline Symptoms & 156 & 42.6 & 130 & 35.5 & 80 & 21.9 \\
\hline General complications & 48 & 13.1 & 238 & 65.0 & 80 & 21.9 \\
\hline Prevention & 41 & 11.2 & 176 & 48.1 & 149 & 40.7 \\
\hline \multicolumn{7}{|l|}{ Infection } \\
\hline Predisposing factors of infection & 132 & 36.1 & 198 & 54.1 & 36 & 9.8 \\
\hline Symptoms of infection & 55 & 15.0 & 269 & 73.5 & 42 & 11.5 \\
\hline Normal body temperature & 205 & 56.0 & 0 & 0.0 & 161 & 44.0 \\
\hline Sites of measurement & 250 & 68.3 & 0 & 0.0 & 116 & 31.7 \\
\hline Sites of cold compresses & 183 & 50.0 & 146 & 39.9 & 37 & 10.1 \\
\hline \multicolumn{7}{|l|}{ Anemia } \\
\hline Meaning of anemia & 291 & 79.5 & 0 & 0.0 & 75 & 20.5 \\
\hline Symptoms of anemia & 167 & 45.6 & 163 & 44.5 & 36 & 9.9 \\
\hline
\end{tabular}

Table (4): Illustrated that, $42.1 \%$ of mothers had correct complete knowledge regarding meaning of leukemia, $59.3 \%$ had correct incomplete knowledge regarding to predisposing factors, $58.8 \%$ had incorrect knowledge regarding to types, $66.9 \%$ had correct complete regarding to commonly affected age group, $42.6 \%$ had correct complete knowledge regarding to symptoms, $83.1 \%$ had correct incomplete knowledge regarding to complications, $65.0 \%$ had correct incomplete knowledge regarding to general complications of leukemia, $48.1 \%$ had correct incomplete knowledge regarding to prevention of leukemia, $54.1 \%$ had correct incomplete knowledge regarding to predisposing factors of infection, $73.5 \%$ had correct incomplete knowledge regarding to symptoms of infection, 56.0\% had correct complete knowledge regarding to normal body temperature, $68.3 \%$ had correct complete knowledge regarding to sites of measurement, $50.0 \%$ had correct complete knowledge regarding to sites of cold compresses, $79.5 \%$ had correct complete knowledge regarding to meaning of anemia, and $45.6 \%$ had correct complete knowledge regarding to symptoms of anemia.

Table (5): Distribution of studied mothers regarding to their knowledge about investigations of leukemia $(\mathrm{n}=366)$.

\begin{tabular}{|l|c|c|c|c|c|c||}
\hline \multirow{2}{*}{ Mothers knowledge about investigation } & \multicolumn{2}{|c|}{$\begin{array}{c}\text { Correct } \\
\text { Complete }\end{array}$} & \multicolumn{2}{c|}{$\begin{array}{c}\text { Correct } \\
\text { Incomplete }\end{array}$} & \multicolumn{2}{c|}{ Incorrect } \\
\cline { 2 - 8 } & No. & $\%$ & No. & $\%$ & No. & $\%$ \\
\hline \hline Types & 83 & 22.7 & 265 & 72.4 & 18 & 4.9 \\
\hline Care before any procedure & 84 & 23.0 & 147 & 40.2 & 135 & 36.8 \\
\hline Importance of bone marrow aspiration & 76 & 20.8 & 230 & 62.8 & 60 & 16.4 \\
\hline Mothers' role after bone marrow aspiration & 90 & 24.6 & 195 & 53.3 & 81 & 22.1 \\
\hline Importance of complete blood picture & 80 & 21.9 & 240 & 65.6 & 46 & 12.5 \\
\hline Mothers' role after aspiration of blood sample & 107 & 29.2 & 146 & 39.9 & 113 & 30.9 \\
\hline
\end{tabular}


Table (5): Indicated that, $72.4 \%$ of mothers had correct incomplete knowledge regarding to types of leukemia investigation, $40.2 \%$ had correct incomplete knowledge regarding to care before any procedure, $62.8 \%$ had correct incomplete knowledge regarding to aim of bone marrow aspiration, $53.3 \%$ had correct incomplete knowledge regarding to mothers role after bone marrow aspiration, $65.6 \%$ had correct incomplete knowledge regarding to aim of complete blood picture, and $39.9 \%$ had correct incomplete knowledge regarding to mothers role after aspiration of blood sample

Table (6): Distribution of studied mothers regarding to their knowledge about leukemia treatment $(\mathrm{n}=366)$.

\begin{tabular}{||l|c|c|c|c|c|c||}
\hline \multirow{2}{*}{$\begin{array}{c}\text { Mothers knowledge about } \\
\text { Treatment }\end{array}$} & \multicolumn{2}{c|}{$\begin{array}{c}\text { Correct } \\
\text { Complete }\end{array}$} & \multicolumn{2}{c|}{$\begin{array}{c}\text { Correct } \\
\text { Incomplete }\end{array}$} & \multicolumn{3}{c|}{ Incorrect } \\
\cline { 2 - 8 } & No. & $\%$ & No. & $\%$ & No. & \multicolumn{1}{c|}{} \\
\hline \hline Types of treatment & 99 & 27.0 & 240 & 65.6 & 27 & 7.4 \\
\hline Aim of chemotherapy & 48 & 13.1 & 297 & 81.1 & 21 & 5.8 \\
\hline Routes of chemotherapy & 18 & 4.9 & 77 & 21.0 & 271 & 74.1 \\
\hline Places of receiving chemotherapy & 102 & 27.9 & 252 & 68.9 & 12 & 3.2 \\
\hline Complications of chemotherapy & 93 & 25.5 & 261 & 71.3 & 12 & 3.2 \\
\hline Meaning of bone marrow transplantation & 182 & 49.7 & 0 & 0.0 & 184 & 50.3 \\
\hline Source for bone marrow donation & 14 & 3.9 & 200 & 54.6 & 152 & 41.5 \\
\hline Aim of blood transfusion & 272 & 74.3 & 0 & 0.0 & 94 & 25.7 \\
\hline Mothers' role during blood transfusion & 67 & 18.3 & 166 & 45.4 & 133 & 36.3 \\
\hline Time of disease relapse & 16 & 4.4 & 120 & 32.8 & 230 & 62.8 \\
\hline Symptoms of relapse & 118 & 32.2 & 0 & 0.0 & 248 & 67.8 \\
\hline Contraindicated drugs & 49 & 13.4 & 181 & 49.4 & 136 & 37.2 \\
\hline Dangerous signs be reported immediately & 85 & 23.2 & 212 & 57.9 & 69 & 18.9 \\
\hline
\end{tabular}

Table (6): Demonstrated that, $65.6 \%$ of mothers had correct incomplete knowledge regarding to types of leukemia treatment, $81.1 \%$ had correct incomplete knowledge regarding to aim of chemotherapy, $74.1 \%$ had incorrect knowledge regarding to rout of chemotherapy, $68.9 \%$ had correct incomplete knowledge regarding to places of receiving chemotherapy, $71.3 \%$ had correct incomplete knowledge regarding to complication of chemotherapy, $50.3 \%$ had incorrect knowledge regarding to meaning of bone marrow transplantation, 54.6\% had correct incomplete knowledge regarding to source of bone marrow donation, $74.3 \%$ had correct complete knowledge regarding to aim of blood transfusion, $45.4 \%$ had correct incomplete knowledge regarding to mothers role during blood transfusion, $75.9 \%$ had correct incomplete knowledge regarding to aim of follow up after stop of drugs, $62.8 \%$ had incorrect knowledge regarding to time of disease relapse, $67.8 \%$ had incorrect knowledge regarding to symptoms of relapse , $49.4 \%$ had correct incomplete knowledge regarding to contraindicated drugs, and $57.9 \%$ had correct incomplete knowledge regarding to dangerous signs be reported immediately. 


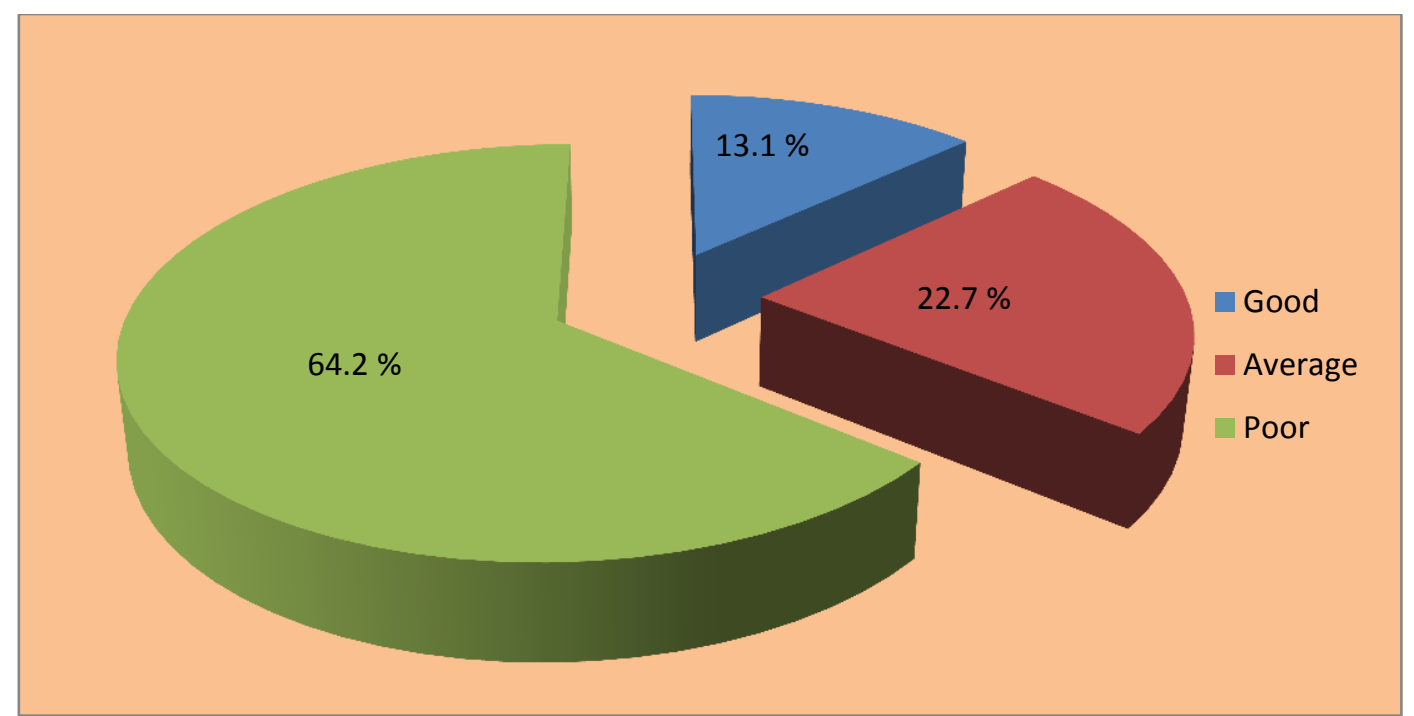

Figure 1: Illustrates that $64.2 \%$ of treatments, where as $22.7 \%$ had studied sample had poor knowledge score about leukemia, investigations, average knowledge score and $13.1 \%$ had good knowledge score.

Table (7A): Distribution of studied mothers regarding their reported practices about leukemia management $(n=366)$.

\begin{tabular}{|l|c|c|c|c|c|c||}
\hline \multirow{2}{*}{ Mother's practices regarding to leukemia } & \multicolumn{2}{|c|}{ Done complete } & \multicolumn{2}{|c|}{ Done incomplete } & \multicolumn{2}{c|}{ Not done } \\
\cline { 2 - 7 } & No. & $\%$ & No. & $\%$ & No. & 17.4 \\
\hline Child follow up & 302 & 82.6 & 0 & 0.0 & 64 & 67 \\
\hline Give the medications at home & 198 & 54.1 & 101 & 27.6 & 18.3 \\
\hline Give the medications according to five right & 75 & 20.5 & 119 & 32.5 & 172 & 47.0 \\
\hline Care of hyperthermia & 84 & 23.0 & 0 & 0.0 & 282 & 77.0 \\
\hline Prevent of infection & 104 & 28.4 & 250 & 68.3 & 12 & 3.3 \\
\hline Prevent of bleeding & 93 & 25.4 & 225 & 61.5 & 48 & 13.1 \\
\hline Care of epistaxis & 105 & 28.7 & 244 & 66.7 & 17 & 4.6 \\
\hline Manage of pain & 35 & 9.6 & 306 & 83.6 & 25 & 6.8 \\
\hline Care of teeth and mouth inflammation & 49 & 13.4 & 258 & 70.5 & 59 & 16.1 \\
\hline Manage of anorexia & 62 & 16.9 & 285 & 77.9 & 19 & 5.2 \\
\hline
\end{tabular}

Table (7A): Revealed that, $82.6 \%$ of mothers did regular child follow up, $54.1 \%$ gave medication at home, $47.0 \%$ didn't follow five rights of medication, $77.0 \%$ didn't care of hyperthermia, $61.5 \%$ did incomplete prevent of bleeding, $66.7 \%$ cared incomplete of epistaxis, $83.6 \%$ did management of pain incomplete, $70.5 \%$ did care of teeth and mouth inflammation incomplete, and $77.9 \%$ did management of anorexia incomplete

Table (7B): Distribution of studied mothers regarding their reported practices about leukemia management $(n=366)$. 
Mothers' Health Care of their Children with Leukemia

\begin{tabular}{|c|c|c|c|c|c|c|}
\hline \multirow{2}{*}{$\begin{array}{l}\text { Mother's practices regarding to } \\
\text { leukemia }\end{array}$} & \multicolumn{2}{|c|}{ Done complete } & \multicolumn{2}{|c|}{ Done incomplete } & \multicolumn{2}{|c|}{ Not done } \\
\hline & No. & $\%$ & No. & $\%$ & No. & $\%$ \\
\hline Care of nausea \& vomiting & 74 & 20.2 & 243 & 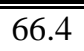 & 49 & $\overline{13.4}$ \\
\hline Encourage the child to eat & 85 & 23.2 & 272 & 74.4 & 9 & 2.4 \\
\hline Manage of anemia & 59 & 16.1 & 301 & 82.2 & 6 & 1.7 \\
\hline manage of fatigue & 63 & 17.3 & 294 & 80.3 & 9 & 2.4 \\
\hline Manage of diarrhea & 135 & 36.9 & 222 & 60.7 & 9 & 2.4 \\
\hline Manage of constipation & 152 & 41.5 & 205 & 56.1 & 9 & 2.4 \\
\hline Care of skin inflammation & 120 & 32.8 & 232 & 63.4 & 14 & 3.8 \\
\hline Care of alopecia & 160 & 43.7 & 164 & 44.8 & 42 & 11.5 \\
\hline Care of urine changes & 92 & 25.1 & 203 & 55.5 & 71 & 19.4 \\
\hline Training the child to future follow up & 199 & 54.4 & 0 & 0.0 & 167 & 45.6 \\
\hline Forms of child follow up & 148 & 40.4 & 117 & 32.0 & 101 & 27.6 \\
\hline
\end{tabular}

Table (7B): Revealed that, $66.4 \%$ did care of nausea and vomiting incomplete, $74.4 \%$ did encourage the child to eat, $82.2 \%$ did manage of anemia incomplete, $80.3 \%$ managed of fatigue incomplete, $60.7 \%$ did manage of diarrhea incomplete, $56.1 \%$ did incomplete manage of constipation, $63.4 \%$ incomplete cared of skin inflammation, $44.8 \%$ incomplete cared of alopecia, $55.5 \%$ incomplete cared of urine changes, and $54.4 \%$ o did trained the child to future follow up.

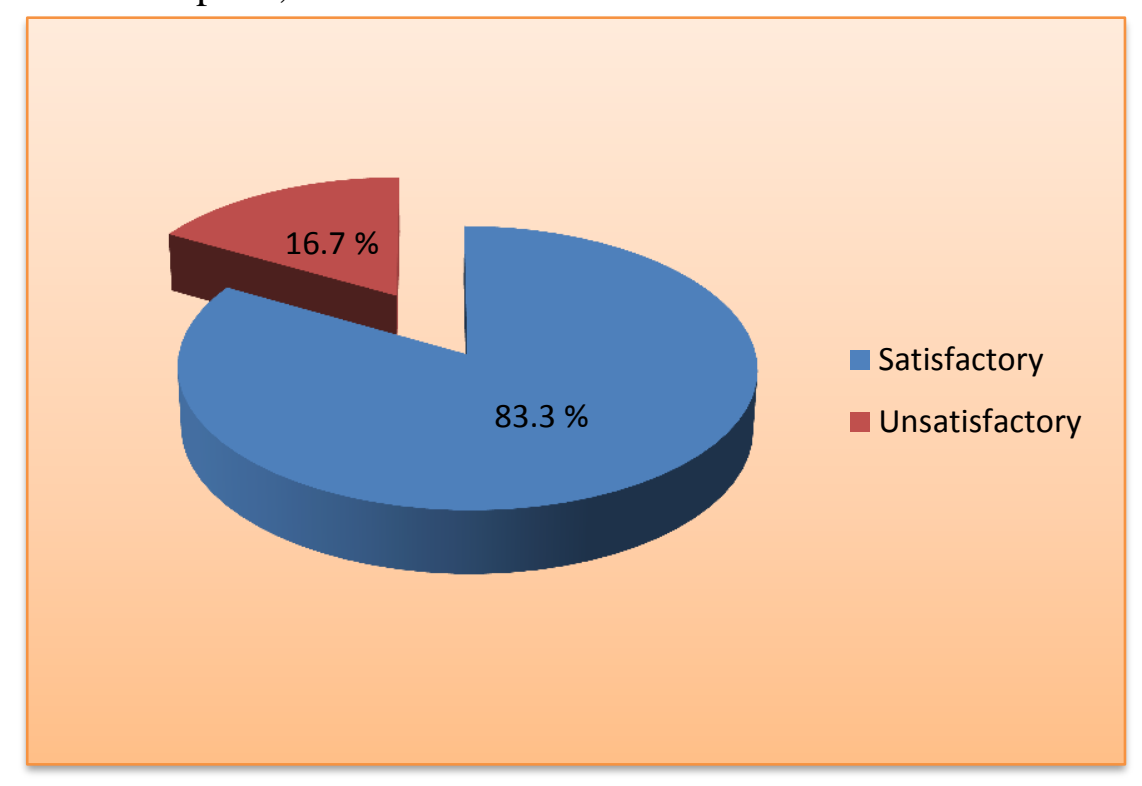

Figure 2: Reveals that, more than three quarters of study sample $83.3 \%$ had satisfactory practices score regarding care of their children with leukemia while, $16.7 \%$ had unsatisfactory practices score.

Table (8): Characteristics of mother having different levels of knowledge about leukemia. 


\begin{tabular}{|c|c|c|c|c|c|c|c|c|}
\hline \multirow{2}{*}{$\begin{array}{l}\text { Demographic characteristics of } \\
\text { mothers' }\end{array}$} & \multicolumn{2}{|c|}{ Poor $(n=235)$} & \multicolumn{2}{|c|}{$\begin{array}{l}\text { Average } \\
(n=83)\end{array}$} & \multicolumn{2}{|c|}{$\operatorname{Good}(n=48)$} & \multirow[t]{2}{*}{$\mathbf{X}^{2}$} & \multirow[t]{2}{*}{ p-value } \\
\hline & No & $\%$ & No & $\%$ & No & $\%$ & & \\
\hline \multicolumn{9}{|l|}{ Age/Years } \\
\hline $18-$ & 32 & 13.6 & 21 & 25.3 & 7 & 14.6 & 16.71 & 0.000 \\
\hline $22-$ & 106 & 45.1 & 25 & 30.1 & 30 & 62.5 & & \\
\hline $32+$ & 97 & 41.3 & 37 & 44.6 & 11 & 22.9 & & \\
\hline \multicolumn{9}{|l|}{ Education } \\
\hline Can't read \& Write & 52 & 22.1 & 21 & 25.3 & 0 & 0.0 & 114.7 & 0.000 \\
\hline Read \& Write & 54 & 23.0 & 11 & 13.3 & 1 & 2.1 & & \\
\hline Primary \& Preparatory & 44 & 18.7 & 25 & 30.1 & 0 & 0.0 & & \\
\hline Secondary & 64 & 27.2 & 5 & 6.0 & 16 & 33.3 & & \\
\hline University & 21 & 8.9 & 21 & 25.3 & 31 & 64.6 & & \\
\hline \multicolumn{9}{|l|}{ Marital status } \\
\hline Married & 130 & 55.3 & 58 & 69.9 & 44 & 91.7 & 48.45 & 0.000 \\
\hline Widow & 33 & 14.0 & 22 & 26.5 & 1 & 2.1 & & \\
\hline Divorced & 72 & 30.6 & 3 & 3.6 & 3 & 6.3 & & \\
\hline \multicolumn{9}{|l|}{ Occupation } \\
\hline Worker & 115 & 48.9 & 25 & 30.1 & 43 & 89.6 & 43.31 & 0.000 \\
\hline Not working & 120 & 51.1 & 58 & 69.9 & 5 & 10.4 & & \\
\hline \multicolumn{9}{|l|}{ Parents' consanguinity } \\
\hline Yes & 99 & 42.1 & 40 & 48.2 & 20 & 41.7 & 0.98 & 0.61 \\
\hline No & 136 & 57.9 & 43 & 51.8 & 28 & 58.3 & & \\
\hline
\end{tabular}

Table $\mathbf{8}$ reveals there was highly statistically significant difference between knowledge of mothers having Discussion

As regards total knowledge score of the studied mothers, this study showed nearly two third of studied sample had poor knowledge score about leukemia, investigations, and treatments (Figure 1). This finding was agreed with American Cancer Society, (2017) which mentioned in a similar study that most of mothers were poorly informed about the treatment and investigation of leukemia. This result indicated with Hani, et al., (2016) who found that, the majority $(90 \%)$ of caregivers had deficient knowledge about treatments different ages, education, marital status and occupation.

and investigations of leukemia. On the same line, Gelesson et al., (2016) who conducted a study on 11 caregivers of children with cancer at chemotherapy outpatient clinic of the pediatric oncology institute of Sao Paulo, Brazil and indicated that, family caregivers of cancer patients had lack of knowledge and needed orientations about the disease.

Also National Comprehensive Cancer Network, (2016) which reported that, family caregivers had lack of knowledge of acute leukemia in 
children undergoing chemotherapy. These results may be related to mother's educational level, place of residence and improper health education programs about their children condition from health care providers.

Concerning follow up for the child the study showed that, more than two third of mothers reported that, there were regular follow up for the children (Table 9A). This result was supported with Leukemia and Lymphoma Society, (2017) who stated that, follow up regimen or chemotherapy protocol was based on the child's type of leukemia and condition and the mothers should discuss with the physician the chemotherapy protocol and any variations in treatment.

Regarding mothers' knowledge about gave medication of the child at home, study result demonstrated that, more than half of mothers gave medication to their children; on the other hand less than half of mothers reported that, they didn't don five right of medication. This finding was in agreement with Gelesson et al., (2016) who showed that, the most of caregivers gave the medication to their leukemic children. This may be due to the frequent questions of mothers about medication. The study indicated that, more than three quarters of the mothers didn't care of hyperthermia. This result finding was agreed with WHO, (2017) who showed that, caregiver's action in case of hyperthermia was hurrying to hospital immediately because they were afraid from child convulsion. This may be due to mothers' educational level.

Regarding to mothers practices about prevention of infection, more than half of mothers' done incomplete prevent the infection. This result was supported with Michele et al., (2016) who revealed that, the majority of family caregivers were avoiding child's contact with ill people and avoid staying in crowded and dusty areas was a measure to prevent child infection. This could be related to the frequent instructions that given to the mothers about measures to prevent child infection from physician and nurses.

The finding of present study revealed that the highest percentage of mothers did manage of epistaxis. This finding was in agreement with James et al., (2015) who found that, most of the caregiver in New York City knows to manage their children suffering from leukemia in developed countries. This may be related to lack of health education about home care of epistaxis or to mothers' fear that their children will lose a lot of blood and that these children are already anemic and this reflect on their health condition and the regularity of their chemotherapy session.

Regarding to management of pain, the finding of the present study revealed that, the majority of mothers had done incomplete. These findings were in agreement with Martinet al., (2016) who indicated that, to relief bone pain, warm compresses should be applied at the site of pain, massage site of pain, and administer analgesic according to doctor order.

As regards care of teeth and mouth inflammation, the finding of the present study showed that, more than two third of studied mothers had done incomplete. According to American Cancer Society, (2016) which found that, the most of caregivers use soft tooth brush and encourage rising mouth with warm water and take her child for regular dental checkup in case of teeth decay. This may be due to the mothers fear from teeth bleeding as these children had the tendency to bleed.

In relation to mothers' practices about anorexia management the present study found that, three fifths of the studied mothers had done incomplete. This 
finding was supported by National Cancer Institute, (2018) mentioned that, there were many theories about the cause of anorexia in cancer patient, alteration in taste manifested by increased salty, sour and metallic taste lead to decreased appetite and decreased nutritional intake. This side effect could be caused by administration of chemotherapy agents. As regarding to care of nausea and vomiting, the present study revealed that more than three fifths of studied mothers had done incomplete (Table 9B). This finding was indicated with Leukemia and Lymphoma Society, (2017) which revealed that, the measures of care in case of nausea and vomiting should include offering small frequent meals and allowing the child to drink water and fluids between meals. In addition fatty, greasy or fried spicy and hot food should be avoided, limit the child's activity as well as avoid favorite food when the child is nauseated.

As regards constipation management, the present study reported that, more than half of studied mothers had done incomplete. This result was agreed with Fouad, (2013) who found that, administering fruits and vegetables, plenty of fluids and providing foods rich in fibers as cereals and bread to treat constipation. This may be related to administering plenty of fluids is the most common and simple known measure of care.

Regarding to care of skin inflammation practices, the finding of the present study revealed that, less than two third of studied mothers had done incomplete practices about skin inflammation. This finding was supported by Health Professional Version, (2016) which mentioned that, the majority of caregivers had adequate knowledge about care of skin inflammation and the measures of care include hand washing before contacting the child, exposing site of inflammation to air to dry, drying skin with compression and applying ointment according to doctor order and caring of children's nutrition. This may because it was the treatment usually prescribed when mothers report to doctors about their childrens skin inflammation and to mothers' believes especially in rural area, that medication is the best for treating any disease.

As regards care of alopecia and, the present study showed that less than half of studied mothers had done incomplete. This finding were in agreed with Zaki \&Soke, (2015) who found that, the majority of family caregivers had adequate knowledge score about care of alopecia, and found that washing the child's head, wearing a scarf or hat or wig and avoid the use of hair pains are measures of care of alopecia. This may be explained in the light of children's psychological feeling with their hair loss and they want to hide their scolded head and cover it.

On accessing relation between mothers' knowledge and their demographic characteristics, the present study indicated that, there was highly statistically significant difference between mother's knowledge and their age, education, marital status, and occupation $(\mathrm{P}=0.000)$. On other hand, there were no statistically significant differences between mother's knowledge and their parent's consanguinity $(\mathrm{P}=0.610)$ (Table 9). This result was supported by Fouad, (2013) and Hassan et al., (2015) who reported a highly statistically significantly between caregivers' knowledge and their age, education, marital status, and occupation. These finding were not in accordance with those of Oncology Nursing Society (ONS), (2017) which mentioned in USA that were no statistically significantly between caregivers' knowledge and their age, education, 
marital status. This difference could be related to different communities and types of health care services.

\section{Conclusion}

Based on the results of the present study and research question, the following can be concluded:

More than three fifths of the mothers had poor knowledge score about leukemia, investigations, and treatments. More than three quarters of study sample had satisfactory reported practices score regarding to care of their leukemic children?

\section{Recommendations}

In the light of the result of present study, the following recommendations are suggested:

- Develop a health education programs for mothers who having leukemic children to prepare them with needed knowledge and skills and improve the public awareness about the early warning signs and symptoms of leukemia.

- Providing Pediatric Oncology Clinic with power point presentation showing mothers' principle steps for caring child with leukemia.

- Further researches should be conducted on a larger scope to explore more about the nursing strategies for caring of the child with leukemia.

\section{References}

American Cancer Society (2016): How is Leukemia Diagnosis? Detailed Guide: Leukemia - Adult Chronic. Available at
http://www.cancer.org/Cancer/Le ukemia. Accessed on: 5/3/2017.

American

Cancer

Society,(2017):Cancer Facts \&

Figures. Retrieved

from:http://www.cancer.org/dow

nloads/ST. Accessed on:7/1/ 2017.

Follin S., Mills E., and Munden J., (2014): Disease: Anursing Process Approach to Excellent Care, 8th ed. J.B. Lippincott Comp. London, PP.395 - 396.

Fouad R., (2013): Family caregivers' knowledge and practice of children with PKU. Master Degree in Nursing Science, Community Health Nursing, Faculty of Nursing, Cairo University.

Gelesson D., Hiraishi L., Ribeiro L., Pereira S., Gutierrez M., and Domenico E., (2016): The meaning of neutropenia and homecare needs according to caregivers of children with cancer, Journal of Clinical Nursing 17(6):933-939.

Hani H., Abdel shafy N., and Kaddah R.,(2016):Neuro-chemical Distortions among Patients with Leukemia Receiving Chemotherapy, The Arab Journal of Psychiatry Vol. 23 No. 1 Page (52-59).

Hassan S., Hussein A., and Hashim M., (2015): Assessment of Home Care Management for Caregivers having Leukemia Adolescents 
Patient in Erbil city, Nurs Sci, 12 (3): $1-13$.

Health Professional Version (2016): Childhood Acute Lymphoblastic Leukemia Treatment (PDQ ®) U.S. National Library of medicine - The World's Largest Medical Library. Available at http://www.ncbi.nih.gov/pubmed health. Acssessed on 11/1/2018.

James G., Gurney A., Malcolm A., Smith P., Julie A., and Ross T., (2015): Cancer Incidence and Survival among Children and Adolescents, US SEER Program, chapter on Leukemia Cancer Statistics, National Cancer Institute. Available at SEER. Accessed on Mar 10, (2017).

Leukemia and Lymphoma Society, (2017): Chronic lymphocytic leukemia.From website: http://www.leukemialymphoma.org/all page.adb. Accesse on: 8/1/ 2017.

Martin, M., Mochamat, H. and Vera, P. (2016): Pharmacological treatments for leukemia associated with palliative care: Executive summary of a Cochrane Collaboration Systematic review, Journal of London, New York, Sarcopenia and Muscle; 7(9): 23-27.

Michele, C., Luis, C. and Lucila, C. (2016): Fatigue in children and adolescents with cancer from the perspective of health professionals 24: 2784.

National cancer institute, (2018): A child Acute Leukemia. Available at

http://www.cancer.gov/cancertop ics/pdq/treatment/achildAML/pat ient. Accessed on: 11/1/ 2018.

National Comprehensive Cancer Network (NCCN), (2016): Chronic myelogenous leukemia. Clinical Practice Guidelines in Oncology. Available at: http;//www.nccn.org/professional /physician-gls/PDF/cml.pdf. Accessed on: 2/2/2017.

Oncology Nursing Society (ONS), (2017): Cancer Treatment. Available

at:

http://www.ons.rg/patient/Ed/Can cer Treatment/index.html. Accessed on: 22/8/2017.

World health organization (2017): The WHO Global Health Observatory and United Nations Department of Economic and Social Affairs.

Zaki, H. and Soke, J. (2015): Health related quality of life of mothers of children with leukemia. Quality of Life Research Journal; 14(4): 1375-2649. 